\title{
Efficiency of Financing High-Tech Industries: The Case of Kazakhstan
}

\author{
Gulnara SADYKHANOVA ${ }^{1}$, Aiman EREZHEPOVA ${ }^{2}$, Biken NURMANOVA ${ }^{3}$, \\ Aida AITBEMBETOVA ${ }^{4}$, Laila BIMENDIYEVA ${ }^{5}$
}

Received: July 06, 2019 Revised: September 16, 2019 Accepted: September 30, 2019

\begin{abstract}
The study aims to build a model for evaluating the effectiveness of activities and the effectiveness of financial investments in hightech industries in Kazakhstan. The development of high-tech industries plays an important role in the economic growth of a country. In this regard, it is relevant to study the effectiveness of financing the most important industry in Kazakhstan. The development of the high-tech sector ensures the efficient functioning of the national innovation system. High-tech enterprises are one of the competitive sectors that allow us to develop and implement leading-edge innovations with the goal of their subsequent commercialization domestically and abroad. The author defines the multicriteria of efficiency in a knowledge-based economy associated with achieving an economic effect with multivariate correlation of results with costs. A multivariate dynamic model, an integral indicator of performance, an integral indicator of cost-effectiveness is proposed. The assessment of the effectiveness of financial costs and performance indicators in all regions of Kazakhstan have the positive dynamics of indicators, as well as a high economic effect. The results of the study can be applied in regional management to adequately assess the effectiveness of high-tech organizations and the effectiveness of financial investments, contribution to ensuring the economic security of the region.
\end{abstract}

Keywords : High-tech Industries, Multi-factor Dynamic Model, Performance Evaluation, Financial Investment Efficiency, Economic Security, Kazakhstan

JEL Classification Code : G18, G38

\section{Introduction}

The level of development of high-tech industries is interconnected with the level of economic development of

1 First Author and Corresponding Author, Candidate of Economics Science, Head, Economics Department, Higher School of Economics and Business, Al-Farabi Kazakh National University. [Postal Address: 71 Al-Farabi Avenue, Almaty, 050040, Kazakhstan] Tel. +77017204897, Email: gulnara.sa@mail.ru

2 Candidate of Economics Science, Economics Department, Higher School of Economics and Business, Al-Farabi Kazakh National University. Email: erezhepova@mail.ru

3 Candidate of Economics Science, Economics Department, Higher School of Economics and Business, Al-Farabi Kazakh National University. Email: nurmanova@mail.ru

4 Candidate of Economics Science, Economics Department, Higher School of Economics and Business, Al-Farabi Kazakh National University. Email: aitbembetova@mail.ru

5 Candidate of Economics Science, Economics Department, Higher School of Economics and Business, Al-Farabi Kazakh National University. Email: bimendiyeva@mail.ru

(c) Copyright: Korean Distribution Science Association (KODISA)

This is an Open Access article distributed under the terms of the Creative Commons Attribution Non-Commercial License (http://Creativecommons.org/licenses/by-nc/4.0/) which permits unrestricted noncommercial use, distribution, and reproduction in any medium, provided the original work is properly cited. the region (Solow, 1957). The economic feasibility of adequate financing of high-tech industries is to invest in human capital, on which future economic returns depend, the multiplier effect of increasing average life expectancy, including the working age population, productivity and labor efficiency (e.g., Geroski \& Machin, 1992; Geroski \& Toker, 1996; Yasuda, 2005). At the same time, these investments should be paid off by the effective activity of scienceintensive organizations. Improving the performance of hightech industries requires an analysis of cost-effectiveness, the search for reserves that allow, within the limits of available resources, to improve quantitative and qualitative indicators of the development of high-tech economy. The creation of high-tech products includes additional stages of research, development and technological development, testing, etc., carried out in a certain sequence, and therefore requires endto-end financing for all interrelated work of the product life cycle - from research and development to mass production and operation (and sometimes disposal).

The need to carry out activities to increase the structural, functional efficiency of financing high-tech industries to 
maximize the rational use of available resources at all levels of management is beyond doubt (Freel, 2007).

Thus, the effectiveness of the industry depends not only on the cost of high-tech production, but also the active implementation of progressive transformations in high-tech organizations, which is especially important in the context of the new technological structure in Kazakhstan. It is of scientific interest to study the problems of the effectiveness of financial investments in high-tech industries: building a model for assessing the relationship between the contribution and return of the industry in question in the framework of ensuring the economic security of the region (Ayyagari, Demirgüç-Kunt, \& Maksimovic, 2014; Gorodnichenko \& Schnitzer, 2013).

\section{Literature Review}

High-tech technologies are currently the basis for the integration of the technological complex of the Republic of Kazakhstan into the international high-tech market and serve as a guarantor of the state's competitiveness. The emergence of fundamentally new areas of scientific research and the intensity of the introduction of inventions in Kazakhstan directly depend on the scientific, technical, economic and financial policies pursued by the country's leadership. As the President of the Republic of Kazakhstan, Nursultan Nazarbayev, indicates that the further progressive development of Kazakhstan against the background of a change in the configuration of the economic systems of most countries should go through the construction of a knowledge-based economy.

The creation of a knowledge-based economy is one of the priority areas in the concept of Kazakhstan becoming one of the 30 most developed countries in the world, which requires increasing the potential of knowledge-based industries. Real underfunding of the scientific infrastructure negatively affects the development of high-tech industries (e.g. Beck, Demirgüç-Kunt, \& Maksimovic, 2008, Demirgüç-Kunt \& Maksimovic, 1998; Rajan \& Zingales, 1998; Cull \& Xu, 2005). According to official statistics, the level of private funding for research and development (R\&D) in Kazakhstan per capita is $\$ 247$, and for public funding for private investment - $\$ 4$, which is a hundred to two hundred times less compared with the leading countries of the world. $R \& D$ expenditures per capita in the countries of the Organization for Economic Co-operation and Development (OECD) reach almost 700 dollars a year, and in the USA, Japan, Israel and Finland - about 1.1 thousand dollars. China, with its population of 1340 million people, is significantly higher than Kazakhstan in the level of expenses spent on research and development, even in Russia the share of government spending on research and development is $\$ 86$.

At present, high technology, becoming independent branches of scientific knowledge and the basis of the technological transformation of the domestic economy, do not receive funding levels corresponding to their status and goals. The effective implementation of high technology is constrained not only by a lack of financial resources, but also by the lack of a scientifically based system of financing science and technology.

The innovative development of the economy of the Republic of Kazakhstan poses a number of the most pressing problems - updating financial theories of reproduction, creating on this basis a fundamentally new system for organizing and financing high-tech industries. The scientific concept of effective financing of high-tech industries should be based on principles that ensure the full and targeted functioning of this system taking into account the risks of funding reduction.

The presence of acute problems of financing research and the implementation of their results in industries determines the relevance of the chosen research topic. The problem of increasing the effectiveness of financing is constantly in the field of view of domestic and foreign scientists. Currently, the definition of the conditions for the effectiveness of innovative activities and the principles of building a financing system is being considered in conjunction with questions of economic theory and the economy of industries. Representatives of classical scientific schools and modern experts in the field of finance have developed a methodology for managing innovative and investment activities, have identified solutions to assess the effectiveness of innovative projects and the factors affecting their implementation (Ayyagari et al., 2010; Ullah \& Wei, 2017).

\section{Analysis of Current Situation in Kazakhstan}

The situation with limited investment funds in the hightech industries that determine Kazakhstan's innovative activity in the economy is being aggravated. Their power is used only by $20 \%$. The state is financing innovation activities to no avail. In order for the costs of science to significantly affect the economy, a complete modernization of the financing system for high-tech industries must be carried out. Budgetary funds that were invested in innovation did not bring about effective GDP growth.

Experts are sure that the problem is that development is not in demand by business, science is not in demand in the real sector of the economy. The reason is seen by the fact that there is no clear orientation of research and there is a general imbalance in the innovation system. Clearly, a $15 \%$ increase in R\&D expenditures should bring an additional $1 \%$ to GDP growth. However, this trend is not observed in Kazakhstan. Another important problem is the imitation nature of the innovation system of the Republic of Kazakhstan, which is focused on borrowing technologies that are already ready, rather than creating their own breakthrough innovations. Based on the foregoing, the main prerequisites for the development of effective methods of financing high-tech industries are: 
- the need to create mechanisms for methodological, informational, consulting and educational support on the financing of high-tech industries;

- the need to develop coordination of the activities of executive authorities and local governments, business associations on financing high-tech industries;

- the need to develop a set of tools for financial support of innovative projects from budget sources;

- the need to develop established procedures and criteria for assessing risk and determining the optimal volume of potential investments;

- development of legislative and regulatory acts on the financing of high-tech industries;

- development of levers for the assessment and monitoring of existing research projects financed from the state budget;

At this stage, we can only talk about the formation of science-intensive industries in Kazakhstan, which may in some sense be a consequence of the underdevelopment of the "triple helix" model:

One: The bulk of fundamental research it is not universities, but institutions of the National Academy of Sciences, while the training of scientific personnel is carried out by universities with a rather weak material and technical base and a modest amount of R\&D funding. Currently, there is a process of integration of university and academic science. Deepening such integration actualizes the problems of joint use of intellectual property and production assets, as well as the development of mechanisms for financing $R \& D$ from budgets of various levels, etc.

Two: Scientific-technical and innovation policy, support of certain types of research and development is under the jurisdiction of a number of ministries and agencies, in the structure of public administration there are also departmental coordinating, consulting and advisory bodies. It is quite difficult to achieve the redistribution of priorities in this system, since the inertial practice of making decisions "from achieved" is in effect.

Three: Insufficient activity of enterprises in terms of the volume and effectiveness of their R\&D and the scientific developments that they order to third-party organizations (including organizations of the state sector of science and universities).

Four: Insufficient amount of state funding for research and the lack of effective tax incentives for the development of the scientific sector.

Five: The isolation of scientific organizations and universities not only from the business sector, but also from each other, leading to duplication of the problems being developed with a shortage of financial resources.

Six: The closest ties of the state are formed with the public sector of science. The rest of science as an organizational mechanism is not formalized; therefore, its possibilities for establishing feedback with state structures are significantly limited.

Thus, the above-mentioned institutional barriers to the development of integration interconnections between business, science and government bodies, along with a shortage of research personnel, innovative ideas, lack of venture financial resources, determine the low efficiency of the State-owned innovative development programs implemented in Kazakhstan and, accordingly, the development of high-tech industries.

For the first time, the need to transfer the Republic of Kazakhstan to innovative economic development at the state level was discussed on July 8, 2004, when the question "On the formation of a national innovation system" was considered at a meeting of the Government of the Republic of Kazakhstan. This strategically important document, approved at the highest level, for the first time defined the tasks of Kazakhstan in the field of scientific and technological policy and innovation. Further, as a result of many years of systematic efforts by the state, innovations were identified as a strategically important area of development of the Republic of Kazakhstan.

The main goal of state innovation policy was to form a balanced sector of research and development and an effective innovation system that would ensure technological modernization of the economy and increase its competitiveness based on advanced technologies, and turn scientific potential into one of the main resources for sustainable economic growth. Thus, the development of innovations and high-tech industries has remained the strategic priority of the Republic of Kazakhstan for more than a dozen years. Despite this, innovations and high-tech industries in Kazakhstan are developing very slowly. For example, the share of produced innovative products in relation to GDP for 2017 in Kazakhstan is 1.6\% of GDP, despite the fact that in 2004 this indicator was $1 \%$. By the level of its technological development, the domestic economy is inferior to the countries of Western Europe, the USA, many states of Asia and Latin America. Domestic exports of high technology make up only $0.3 \%$ of China's exports, $3.7 \%$ of US exports, $4.3 \%$ of Japanese exports.

The trend of the enormous technological lag of the Republic of Kazakhstan from the leading countries is caused by the strong dependence of the economy on extractive and manufacturing industries. Due to the resource dependence of the Kazakhstan economy, there is a lack of investment in innovative developments that can significantly reduce this gap. Domestic products of almost all promising areas are uncompetitive against the background of similar products manufactured in China, the USA, Germany, Japan and even the CIS countries. Kazakhstani enterprises in the field of high-tech products are not able to meet domestic demand and, as a result, cannot break into foreign markets.

According to global trends, the demand for research and intellectual knowledge in a knowledge-based economy is constantly growing. In highly developed countries, this is reflected in a constant increase in the financing of science and the salaries of scientists compared with the average economy. However, in Kazakhstan, the general trend of investment in science is somewhat different from the global 
one. In general, the dynamics of the share of $R \& D$ expenditures in relation to the GDP of developed countries and Kazakhstan is shown in Figure 1.

In the period from 1996 to 2015 , China has seen a fairly significant increase in the share of $R \& D$ expenditures in
GDP: from $0.5 \%$ to $2,1 \%$. However, Israel remains the leader in $R \& D$ spending. If in absolute terms $R \& D$ expenditures in Kazakhstan increased by $500 \%$, then the share of R\&D expenditures in GDP over the past 20 years has not changed and is less than $0.2 \%$.

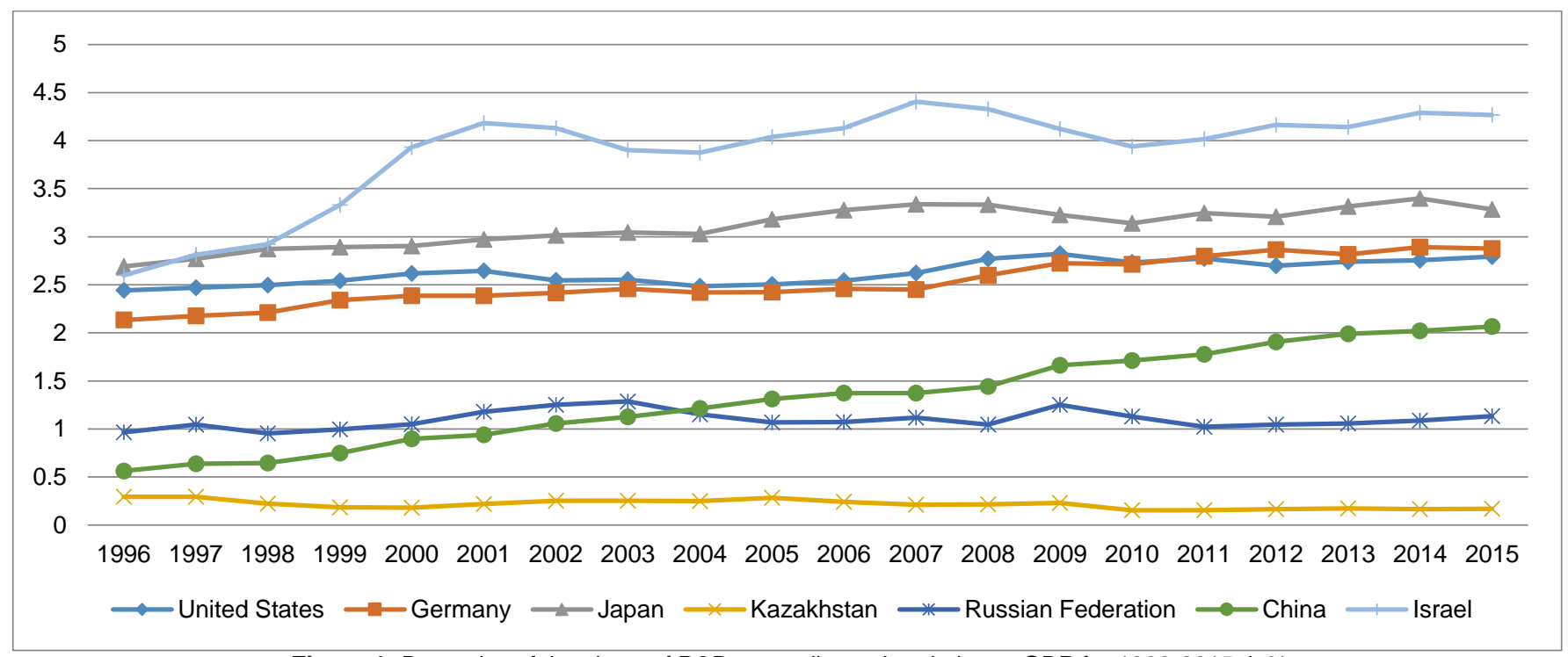

Figure 1: Dynamics of the share of R\&D expenditures in relation to GDP for 1996-2015, in\%

Per capita spending indicators, according to 2016 data, also confirm statistics on a catastrophically low level of funding. This indicator in Kazakhstan is almost ten times less than in the USA, Finland, Sweden, Japan. It is also interesting to compare the internal costs of research and development per one researcher. So, in the USA 387.8 thousand US dollars are spent for one scientist, in the EU countries - 188.4 thousand US dollars, while in Kazakhstan this figure is only 12.3 thousand US dollars, even Russia, he 48.1 thousand dollars. USA.

From an analysis of the data presented, one can see that huge gap in the level of funding for science, which unambiguously dooms Kazakhstan in the near and medium term to a catch-up type of development. The transformation of science under the conditions of the knowledge economy into the most important factor of production also determines the growth of investment in this sector. So, in the USA in 2016, expenditures on science accounted for more than $1 / 3$ of total global expenditures - $30 \%$. This is more than in 28 EU countries combined - 20\%, in China - $14 \%$.

It should be noted that the industry 4.0 development paradigm, based on its high-tech economic nature, defines new requirements for the resource base, which is ensured by the quality and efficient use of intellectual capital. This fact objectively limits the further economic growth of Kazakhstan due to the extraction and export of natural resources and actualizes the need to finance science on an advancing principle.

The "Strategic Plan for the Development of Kazakhstan until 2025" adopted at the beginning of 2018, which is a detailed strategy with clear goals, priorities and a set of tools, is in some accents conceptually consistent with the directions of the "OECD Innovation Strategy", since it starts the processes of the Third Modernization of the country, announced by the Head of State in early 2017, and sets goals for accelerated high-quality economic growth and improving the standard of living in the country. Among the seven priority policies of the adopted Strategic Plan - 2025, two are directly aimed at developing a knowledge-based economy: the formation of new human capital, technological renewal and digitalization of production; the remaining five priorities - to one degree or another, contribute to the transition of the country to the economy of knowledge.

According to ongoing research in the field of innovation, the key factors in the development of high-tech industries are new knowledge generated by skilled labor and the adequacy of funding for research. Thus, you can clearly see which sector of the economy will bring increasing returns in the near future - this is the sector of high-tech and high-tech products. This sector will be the core of the new VI technological order. Note that the new technological structure in terms of its economic efficiency sets new requirements for the resource base. Further development, as can be seen, through the production and export of hydrocarbons is simply unrealistic. Accordingly, the priority financing of science according to the leading principle is the only right way of development.

If we talk about the most important component of the development of high-tech industries - financing of the scientific sector, then in Kazakhstan the following tools are used to varying degrees: 
- assistance in paying for the development or examination of a comprehensive investment project plan

- subsidies to pay for long-term leasing financing;

- innovative grants;

- national innovation competition;

- the provision of professional services for expert and brokerage support of technology transfer for business;

- development of the ecosystem of business incubation, support for technological entrepreneurship;

- project and venture financing.

The main actors in implementing the measures of state financial support for high-tech industries can highlight the development of venture financing in Kazakhstan, which is accompanied by conflicting results. In our country, venture financing has been developed since 2003-2004. In 2003, the National Innovation Fund JSC was established (now the National Agency for Technological Development JSC NATD), which has become an important element of the innovation system of Kazakhstan. To date, four venture capital funds are functioning in Kazakhstan. Over the past 5 years, all Kazakhstan funds in total have completed about 12-15 transactions, and should have been 50-60. Each fund during its investment period, with the effective development of capital, on average had to conclude 10 transactions. The average investment per project was $\$ 2.5$ million. For comparison, in the European Union in 2010, venture capital funds invested 43 billion euros in 5033 companies, which is an average of more than 8 million euros per company. The volume of venture investments in a number of countries (Sweden, Great Britain, and Norway) exceeds $0.5 \%$ of GDP with an average European indicator of $0.3 \%$.

It should be noted that over the period of existence, most domestic venture capital funds have demonstrated low work efficiency; they financed projects in traditional sectors: wholesale and retail trade, construction (production of crushed stone, reinforced concrete structures), etc., while the goal of attracting private capital to innovation was not achieved. For a number of projects, the funds received losses and non-repayment of funds in the amount of 11,834.2 million tenge. Thus, analyzing the current state of venture financing in Kazakhstan, we have to admit that it is at the initial stage of formation. One of the factors hindering the development of venture financing is the shallow capacity of the stock market, in contrast to Western countries, where the growth dynamics of venture funds is also associated with the development of the stock market. Often, venture capital investments in a particular project at the more mature stages of the project are realized through an IPO. The simplicity of the withdrawal procedure is an important advantage that determines the interest of venture capital funds / investors.

In order for the main factors in the development of high technology production - new knowledge and financial resources - to become real drivers for the development of the knowledge economy in Kazakhstan, state policy should focus on ensuring the appropriate institutional conditions: legal, socio-economic, and organizational.
The priority mechanisms for implementing innovation policy are: the formation of institutional and legislative conditions for positive changes in the innovation sphere; state support and stimulation of high-tech, high-tech industries through the introduction of certain tax benefits, state guarantees and loans; improvement of the tax system in order to create favorable conditions for innovative activities; foreign economic support, providing for the creation of conditions for the formation of joint organizations with foreign partners for the production of domestic high-tech products and their sale on the foreign market; providing quotas in foreign credit lines for the development of innovative infrastructure, equipment purchases in order to implement highly efficient projects under state guarantees and technology and know-how licenses for mastering the production of the latest products; consolidation of efforts of state authorities and private investors aimed at organizing interaction with EU countries, the CIS, etc.; development of leasing of high technology unique equipment; participation of innovatively active organizations in international competitions; allocation of direct public investment for the implementation of innovative programs and projects that are nationwide in nature, but not attractive to private investors.

\section{Research Methods and Materials}

When assessing the effectiveness of the economic development of a country and a region, the most important criterion for optimality today is the economic criterion, which reflects the results of the functioning of not only traditional production, but also knowledge-intensive (e.g., Hoskisson, Hitt, Johnson, \& Grossman, 2002; Djankov, McLiesh, \& Shleifer, 2007; Cull \& Xu, 2005). This indicator is a higher step in the hierarchy of social criteria. We determine the multi-criteria effectiveness in high-tech industries in the variety of effects obtained: social, economic, as well as multivariate correlations of results with costs, consideration of the most rational use of financial investments in the industry. It is necessary to achieve the maximum useful effect with limited resources. Improving the economic security of the region largely depends on the achievements of social and economic efficiency in high-tech industries, contributing to the preservation of the human, including able-bodied potential of the population, economic growth. It is advisable to conduct a study of the assessment of costs and returns in the industry on the example of financing and performance indicators in all regions in order to assess and identify backward regions.

To assess the effectiveness of financial costs in high-tech industries, it is necessary to create a multifactor model that allows us to evaluate the effectiveness of the service and the effectiveness of financial costs (Table 1). The descriptive model we have proposed is built on the basis of multivariate analysis, which allows us to dynamically study the influence of external and internal factors and cause-effect relationships, considers the increase (or decrease) in the effective 
performance of high-tech industries, the economic effect (or loss). The dynamic model reflects the high variability of external and internal factors affecting the development of high-tech industries, and, ultimately, the contribution of high-tech industries to ensuring the economic security of the region.

Table 1: Multifactor model for assessing the effectiveness of financial costs in high-tech industries

\begin{tabular}{|c|c|c|c|c|}
\hline $\begin{array}{l}\text { Region as an } \\
\text { economic system }\end{array}$ & \multicolumn{3}{|l|}{ Mesoscale } & Results \\
\hline \multirow[t]{3}{*}{$\begin{array}{l}\text { The level of economic } \\
\text { development of the } \\
\text { region }\end{array}$} & \multirow[t]{3}{*}{$\begin{array}{l}\text { Economic security } \\
\text { of the region }\end{array}$} & \multicolumn{2}{|l|}{ External factors } & $\begin{array}{l}\text { Achieving the multiplier effect of } \\
\text { investments in high-tech industries, its } \\
\text { economic return }\end{array}$ \\
\hline & & Unemployment rate & Job creation & $\begin{array}{l}\text { Obtaining patents and copyright } \\
\text { certificates }\end{array}$ \\
\hline & & Infrastructure & $\begin{array}{l}\text { Infrastructure } \\
\text { development }\end{array}$ & Innovation development \\
\hline \multirow{3}{*}{$\begin{array}{l}\text { The level of economic } \\
\text { development of the } \\
\text { region }\end{array}$} & \multicolumn{3}{|l|}{ Meso and micro level } & Results \\
\hline & \multicolumn{3}{|l|}{ Intrinsic factors } & \\
\hline & $\begin{array}{l}\text { Economic security } \\
\text { of the region }\end{array}$ & $\begin{array}{l}\text { Knowledge } \\
\text { Management Level }\end{array}$ & $\begin{array}{l}\text { Worldwide knowledge } \\
\text { dissemination }\end{array}$ & $\begin{array}{l}\text { Number of articles in journals indexed } \\
\text { by Web of Science and Scopus }\end{array}$ \\
\hline
\end{tabular}

We have proposed an integrated performance indicator (IPI) - the product of a change in the performance indicators of high-tech industries:

IPI $=\Delta$ Articles $\times \Delta$ Patents $\times \Delta$ Copyright certificates $\times$ $\Delta$ Innovations, (1)

where is IPI - integrated performance indicator;

$\Delta$ Articles - change the number of articles in journals indexed by Web of Science and Scopus;

$\Delta$ Patents - change in the prevalence rate of the number of patents;

$\Delta$ Copyright certificates - change in the indicator of the number of copyright certificates;

$\Delta$ Innovations - change in the number of developed innovations.

The standard value - 1, indicates the absence of significant changes. In dynamics, the inverse ratio of the base period to the reporting period is calculated. If the indicators are less than 1, this indicates a deterioration in the performance of the service: morbidity, mortality in dynamics have increased. The indicator above 1 shows positive trends.

The change in the indicator of expenditures (financing of the service) - ( $\Delta$ expenditures $)$ is calculated as the ratio of the reporting indicator to the base. The standard value is 1 , an indicator above 1 indicates an increase in costs, less than 1 indicates a deterioration in funding.

The following factors influence the change of this factor: the level of financing, inflation, and resource provision in terms of cost recovery.

The integrated indicator of cost-effectiveness shows the ratio of the integrated indicator of the effectiveness (IIE) of the service to the indicator of changes in costs (financing):

IIE $=$ IPI / $\Delta$ expenditures (2)

The standard value is 1 . If, despite the increase in funding, performance indicators have deteriorated (morbidity, mortality, etc. have not decreased or increased), then an indicator will be less than 1 , so the money spent is used inefficiently.

A situation may arise in the reduction of financing over time, then the value of the indicator of cost-effectiveness is interesting in terms of the possibility of achieving positive results. The calculation of this indicator requires a multivariate analysis - studying the causes of the deterioration of individual indicators, the adequacy of the structure of financial costs.

\section{Results}

To calculate the indicator of the integrated indicator of the effectiveness in high-tech industries in the regions of Kazakhstan, it is necessary to calculate the indicators indicated in Table 2. 
Gulnara SADYKHANOVA, Aiman EREZHEPOVA, Biken NURMANOVA, Aida AITBEMBETOVA, Laila BIMENDIYEVA

I Journal of Asian Finance, Economics and Business Vol 6 No 4 (2019) 287-295

Table 2: Data for calculating the integrated indicator of the effectiveness in high-tech industries in the regions of Kazakhstan

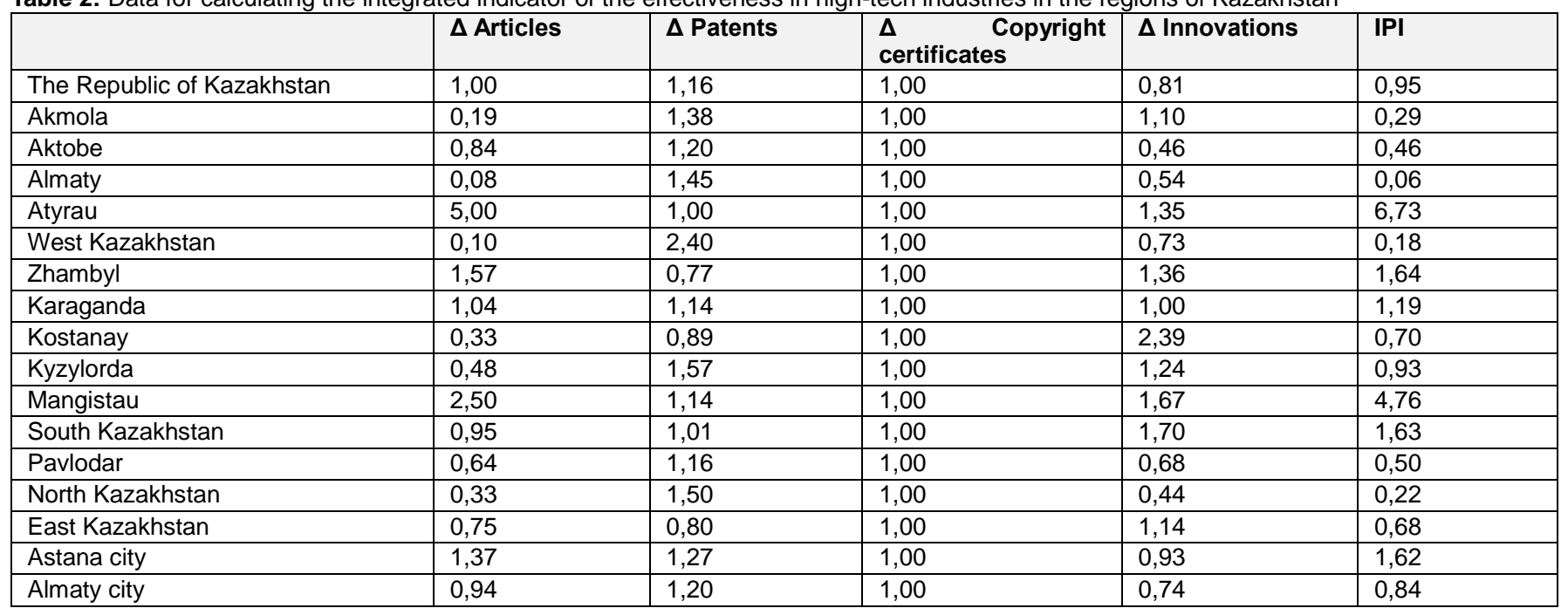

Table 3: Evaluation of the effectiveness and integrated indicator of the effectiveness in high-tech industries in the regions of Kazakhstan

\begin{tabular}{|l|l|l|l|}
\hline & IPI & $\Delta$ expenditures & IIE \\
\hline The Republic of Kazakhstan & 0,95 & 1,03 & 0,919268 \\
\hline Akmola & 0,29 & 1,13 & 0,255727 \\
\hline Aktobe & 0,46 & 1,10 & 0,420121 \\
\hline Almaty & 0,06 & 0,93 & 0,064831 \\
\hline Atyrau & 6,73 & 1,32 & 5,094323 \\
\hline West Kazakhstan & 0,18 & 0,17 & 1,07709 \\
\hline Zhambyl & 1,64 & 2,24 & 0,729922 \\
\hline Karaganda & 1,19 & 0,82 & 1,457766 \\
\hline Kostanay & 0,70 & 2,09 & 0,334123 \\
\hline Kyzylorda & 0,93 & 0,83 & 1,131831 \\
\hline Mangistau & 4,76 & 1,03 & 4,617973 \\
\hline South Kazakhstan & 1,63 & 0,76 & 2,132269 \\
\hline Pavlodar & 0,50 & 0,86 & 0,585449 \\
\hline North Kazakhstan & 0,22 & 1,03 & 0,21463 \\
\hline East Kazakhstan & 0,68 & 1,44 & 0,471972 \\
\hline Astana city & 1,62 & 1,16 & 1,38723 \\
\hline Almaty city & 0,84 & 0,95 & 0,881126 \\
\hline
\end{tabular}

This system is aimed at the algorithmizing of expenditures in high-tech industries in the regions of Kazakhstan on the basis of determining the dynamics of indicators of achievement (increasing the number of patents, innovations, etc.) and indicators of use. The use of medical innovations, dynamic analysis and monitoring of indicators using an information-analytical system, telecommunication technologies allow you to quickly manage high-tech organizations.

The studies and the results confirm the authors hypothesis - they show the possibility of achieving high values of economic efficiency of indicators in the most priority areas of the development of high-tech industries at all levels of management in the industry due to improved financing, the active implementation of organizational and informational innovations. 


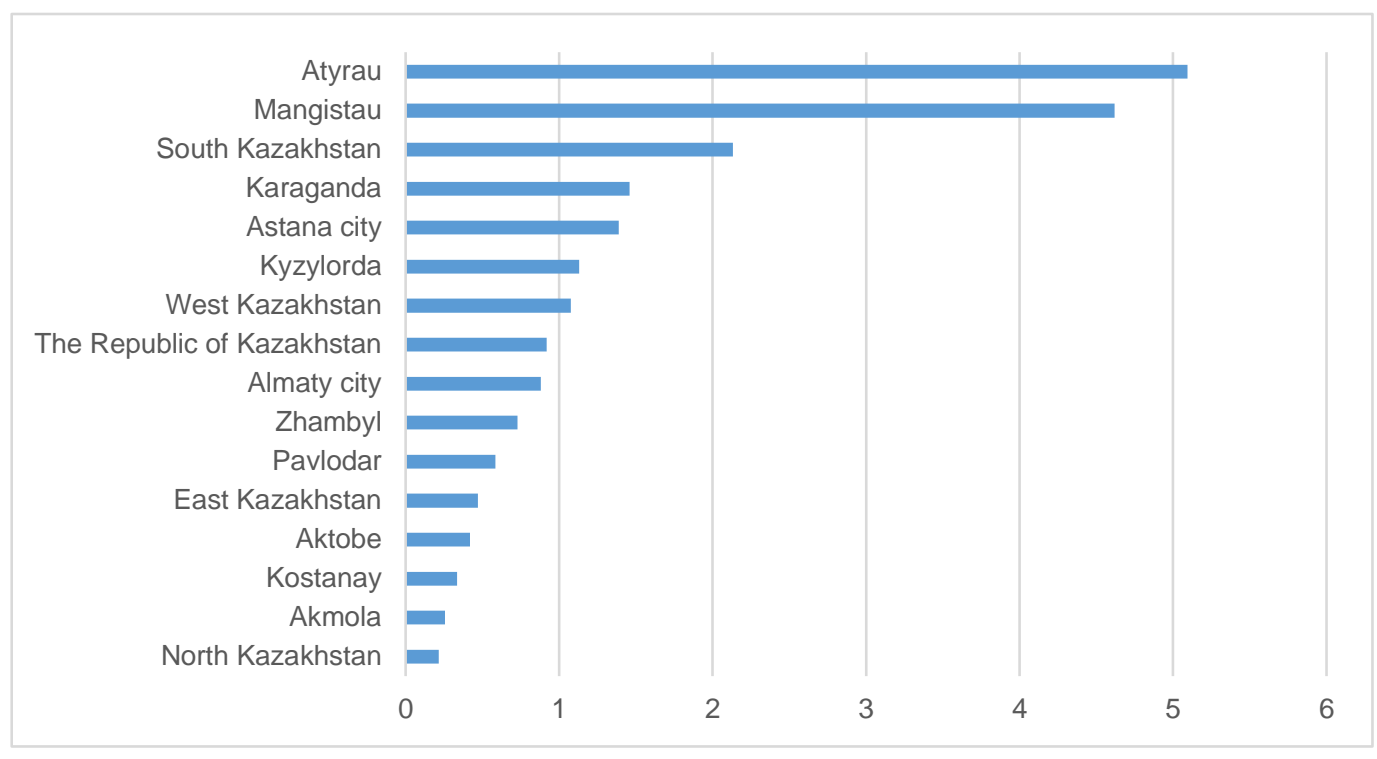

Figure 2: The rating of regions in the integrated indicator of the effectiveness

\section{Conclusions}

As a result of the study, the need for mutually directed processes to reduce human losses, including the labor potential of the population, was determined: increasing the state level of financing high-tech industries with the rational use of resources and enhancing the management of the industry. The multicriteria of the effectiveness of high-tech industries, its relationship with the economic security of the region is considered. A dynamic multifactor model is proposed for assessing the effectiveness of activities and the effectiveness of financial costs in high-tech industries, taking into account the high variability of external and internal factors, directions for increasing controlled factors to improve the functioning of high-tech organizations.

The results obtained are relevant to use for an adequate assessment of financial investments and returns to high-tech industries, taking into account the specifics of the industry in the study of external factors, determining the contribution of the industry at the regional level to the preservation of human capital, ensuring economic security.

Thus, only the consistent and comprehensive implementation of legislative, organizational and socioeconomic measures of government policy will, in our opinion, make a qualitative breakthrough in the development of high-tech industries in the Republic of Kazakhstan.

\section{References}

Ayyagari, M., Demirgüç-Kunt, A., \& Maksimovic, V. (2010). Formal versus informal finance: Evidence from China. The Review of Financial Studies, 23(8), 3048-3097. https://doi.org/10.1093/rfs/hhq030

Beck, T., Demirgüç-Kunt, A., \& Maksimovic, V. (2008).
Financing patterns around the world: Are small firms different? Journal of Financial Economics, 89(3), 467487.

Brown, J. R., Martinsson, G., \& Petersen, B. C. (2012). Do financing constraints matter for $\mathrm{R} \& \mathrm{D}$ ? European Economic Review, 56(8), 1512-1529. https://doi.org/10.1016/j. euroecorev.2012.07.007.

Cull, R., \& Xu, L. C. (2005). Institutions, ownership, and finance: The determinants of profit reinvestment among Chinese firms. Journal of Financial Economics, 77(1), 117-146

Demetriades, P. O., \& Rousseau, P. L. (2016). The changing face of financial development. Economics Letters, 141, 87-90. https://doi.org/10.1016/j.econlet.2016.02.009

Fernandez, V. (2017). The finance of innovation in Latin America. Journal of International Review of Financial Analysis, $\quad 53, \quad 37-47$. https://doi.org/10.1016/j.irfa.2017.08.008.

Freel, M. S. (2007). Are small innovators credit rationed? Small Business Economics, 28(1), 23-35. https://doi.org/10.1007/s11187-005-6058-6.

Geroski, P., \& Machin, S. (1992). Do innovating firms outperform non-innovators? Business Strategy Review, 3(2), 79-90.

Geroski, P. A., \& Toker, S. (1996). The turnover of market leaders in UK manufacturing industry, 1979-86. International Journal of Industrial Organization, 14(2), 141-158

Gorodnichenko, Y., \& Schnitzer, M. (2013). Financial constraints and innovation: Why N. H. Wellalage and V. Fernandez International Review of Financial Analysis $\mathrm{xxx}(\mathrm{xxxx}) \operatorname{xxxx} 13$ poor countries don't catch up. Journal of the European Economic Association, 11(5), 1115-1152. https://doi.org/10.1111/jeea.12033

Hoskisson, R. E., Hitt, M. A., Johnson, R. A., \& Grossman, 
W. (2002). Conflicting voices: The effects of institutional ownership heterogeneity and internal governance on corporate innovation strategies. Academy of Management Journal, 45(4), 697-716.

Howells, J. (2005). Innovation and regional economic development: A matter of perspective? Journal of Research Policy, 34(8), 1220-1234. https://doi.org/10.1016/j. respol.2005.03.014.

Djankov, S., McLiesh, C., \& Shleifer, A. (2007). Private credit in 129 countries. Journal of Financial Economics, $84(2)$, 299-329. https://doi.org/10.1016/j.jfineco.2006.03.004.

Solow, R. M. (1957). Technical change and the aggregate production function. The Review of Economics and Statistics, 39(3), 312-320.

Szirmai, A., Naudé, W., \& Goedhuys, M. (2011). Entrepreneurship, innovation, and economic development. Oxford, UK: Oxford University Press.
Rajan, R. G., \& Zingales, L. (1998). Financial dependence and growth. The American Economic Review, 88(3), 559-586.

Rubin, D. B. (2001). Using propensity scores to help design observational studies: Application to the tobacco litigation. Health Services and Outcomes Research Methodology, 2(3-4), 169-188. https://doi.org/10.1023/A:1020363010465

Ullah, B., \& Wei, Z. (2017). Bank financing and firm growth: Evidence from transition economies. Journal of Financial Research, 40(4), 507-534.

$\mathrm{Wu}$, J., Si, S., \& Wu, X. (2016). Entrepreneurial finance and innovation: Informal debt as an empirical case. Strategic Entrepreneurship Journal, 10(3), 257-273. https://doi.org/ 10.1002/sej.1214.

Yasuda, T. (2005). Firm growth, size, age and behavior in Japanese manufacturing. Small Business Economics, 24, $1-15$. 